Volume 3, Issue 4, Year 2019, pp. 311-318

E - ISSN: 2587-3008

URL: http://ratingacademy.com.tr/ojs/index.php/jsp

DOI: https://doi.org/10.26900/jsp.3.032

Research Article

\title{
FEASIBILITY OF NEARLY-ZERO ENERGY BUILDING RETROFITS BY USING RENEWABLE ENERGY SOURCES IN AN EDUCATIONAL BUILDING ${ }^{1}$
}

\author{
Cihan TURHAN * \& Filiz BAL KOÇYİĞIT ** \& \\ Merter Acar ZİNKÇI *** \& Miromid SAYESTHNOM ****
}

* Asst. Prof. Dr., Atıllm University, Faculty of Engineering, Department of Energy Systems Engineering, TURKEY, e-mail: cihan.turhan@atilim.edu.tr ORCID ID: https://orcid.org/0000-0002-4248-431X

** Assoc. Prof. Dr., Attllm University, Faculty of Art, Design and Architecture, Department of Architecture, TURKEY, e-mail: filiz.kocyigit@atilim.edu.tr ORCID ID: https://orcid.org/0000-0003-4191-0724

*** Student, Atılim University, Faculty of Art, Design and Architecture, Department of Architecture, TURKEY, e-mail: merteracar@hotmail.com ORCID ID: https://orcid.org/0000-0003-1405-1418

**** Student Miromid Sayesthnom, Attlim University, Faculty of Art, Design and Architecture, Department of Architecture, TURKEY, e-mail: omid.shayestehnam@gmail.com ORCID ID: https://orcid.org/0000-0002-5935-1281

Received: 05 July 2019; Accepted: 21 August 2019

\section{ABSTRACT}

Dissemination of education is vital especially in developing countries like Turkey. Besides, proper use of energy resources is required while dissemination of education is ensured. Considering the regions where energy is limited, renewable energy sources should be used to achieve the goal of a zeroenergy building. Moreover, an increase of smart technologies has potantial in order to decrease energy consumption in educational buildings. This paper aims to investigate renewable energy sources to decrease energy consumption to achieve nearly-zero energy building goal by implementing different energy efficient retrofitting scenarios. The retroffitting scenarios are based on renewable energy sources and are presented for an educational building located in Ankara-Turkey, through a Building Energy Simulation Tool, Design Builder Software. In order to develop an accurate model, educational building is monitored and the model is calibrated. Then, various energy efficient retrofitting scenarios are defined such as implementing PV panels, solar collectors and adding wind turbines for electricity generation.

Keywords: Nearly-zero energy buildings, Educational buildings, Renewable energy 


\section{INTRODUCTION}

Energy intensity of Turkey is higher compared with Western European countries. However, energy consumption of the country is expected to grow significantly together with increasing young urban population and industrial development potential. At the same time, elementary education of population in rural region is vital with the development of industry (Tonguc Vakfi, 2019). Besides dissemination of education, proper use of energy resources become a significant issue in developing countries such as Turkey where energy is limited. On the other hand, the building sector holds significant opportunity as $40 \%$ of the current energy consumption (Eshraghi et al., 2014). Therefore, the implementing zero-energy building applications becomes crucial to meet energy saving goals, specially for educational buildings. For example, Ascione et al. (2015) provided renewable energy resources for an educational building in Italy. The authors investigated potential energy savings such as changing glazing with efficient ones and insulating roofs and calculated pay-back period as 10 years. Similarly, Sait (2013) suggested to increase the efficency of air-conditioner systems of educational buildings. $31 \%$ of energy was saved with a pay-back period of 2.3 years.

Nearly-zero energy building (NZEB) is not new concept for educational buildings in Europe. Zeiler and Boxem (2013) compared NZEBs with traditional educational buildings in Netherlands. The authors indicated that NZEBs produces their own energy from renewable energy resources such as solar panels and wind turbine parks. However, initial costs of investments were found high. Considering there are approximately sixty thousand schools in Turkey, educational buildings have great energy saving potential by applying energy efficient retrofit scenarios (Basarir et al., 2012). Moreover, energy efficient educational buildings can improve thermal comfort of students and teachers while decreasing energy consumption of buildings. Many papers have been published to revive educational buildings in rural regions (Tonguc Vakfi, 2019; Vexliard and Aytaç, 1964; Eshraghi et al., 2014; Korur, 2002; Karaomerlioglu, 1998). According to the authors' knowledge, there is no study on predicting energy consumption of educational buildings in rural zones and implementing energy efficient retrofits in Turkey.

The aim of this study is to apply nearly zero-energy applications to an educational building in a rural region. Hasanoğlan Atatürk Science High School which is located in Ankara/Turkey is selected as case building. A detailed building energy simulation tool is used to determine the influence of energy efficient retrofit scenarios. The model of Hasanoğlan Atatürk Science High School is calibrated by comparing the measured and simulated indoor air temperatures and total electricity consumptions. The applicability of the scenarios are evaluated with pay-back period criteria.

\section{CASE STUDY}

Ankara is situated in Central Anatolia Region of Turkey (at 32.52 E $39.56 \mathrm{~N}$ ) which is Dsb type climate zone under the Koppen-Geiger climate classification (World Map of KoppenGeiger Climate Classification, 2006). The average temperature is $22.3^{\circ} \mathrm{C}$ and $1.4^{\circ} \mathrm{C}$ during summer (May-October) and winter (December-March), respectively (Turkish State Meteorological Service, 2019). The case building is the Hasanoğlan Atatürk Science High School which is located in Ankara and lays on Northeast- Southwest direction (Figure 1). 
Figure 1. The location of the Hasanoglan Atatürk Science High School

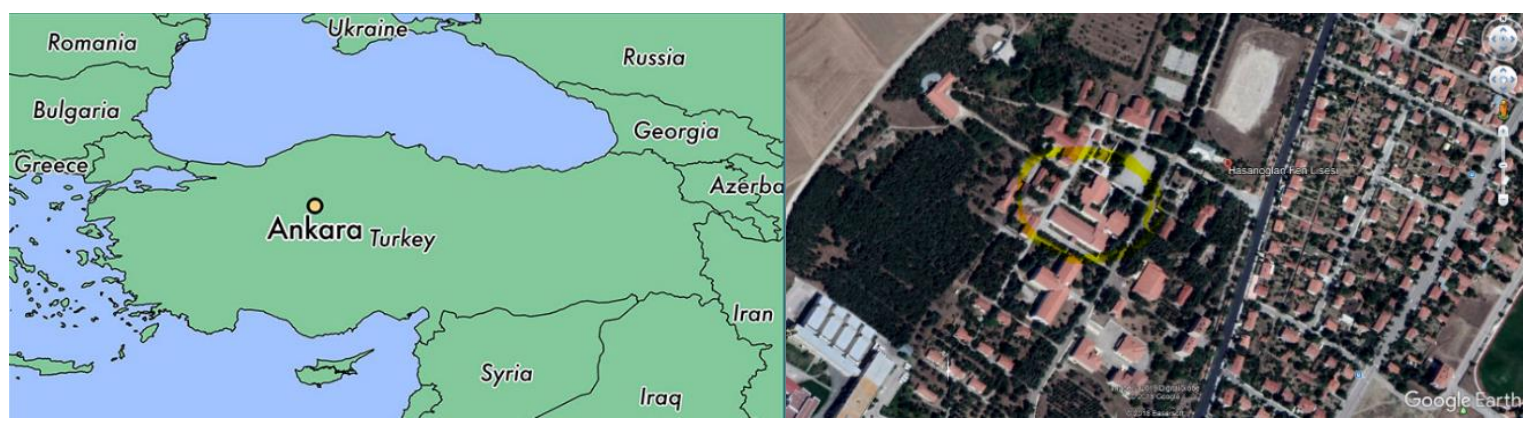

Hasanoglan Atatürk Science High School was built in 1941 by village institute students who founded other village institutes and the teachers to solve the failure in constituting the teaching staff problem for Turkey (Figure 2). The selected building is one-storey with 18 seperate zones. The total floor area of the case flat is $150.85 \mathrm{~m}^{2}$ including administrator offices, editorial offices and long corridors. The people density is assumed as $0.11 \mathrm{ppl} / \mathrm{m}^{2}$ while density of computers is $1 \mathrm{~W} / \mathrm{m}^{2}$. Since there are many editorial offices in the building, the density of office equipments is selected as $11 \mathrm{~W} / \mathrm{m}^{2}$.

Figure 2. The out-view and model of the case building

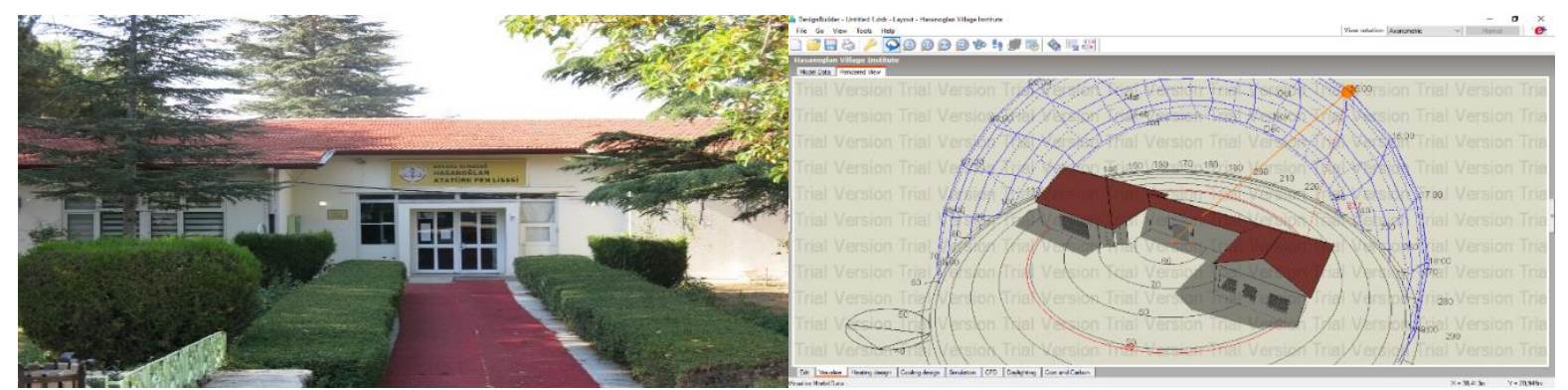

The heating and cooling system of the flat is fan-coil unit $(\mathrm{COP}=1.8)$ with no fresh air. The heating period is 6 months (October-April) with a set point temperature of $23^{\circ} \mathrm{C}$ and the cooling period is approximately 3 months from June to September with the same temperature. The operation period of heating and cooling system is from 08.00 to 19:00 on weekdays. The exterior walls consist of inner gypsum plastering $(0.02 \mathrm{~m})$, brickwork inner leaf $(0.19 \mathrm{~m})$, XPS extruded polystyrene $(0.05 \mathrm{~m})$ and outer gypsum plastering $(0.03 \mathrm{~m})$, respectively. The walls are well-insulated with $5 \mathrm{~cm}$ XPS. The doors and the windows are double glazed with a PVC frames. Air tightness of the elements is $0.7(1 / \mathrm{h})$.

The Hasanoglan Atatürk Science High School is modelled and simulated in a Building Energy Simulation (BES) tool, DesignBuilder (2019). DesignBuilder is a 3D BES tool which uses EnergyPlus simulation engine. The software is capable of modelling buildings according to their heating/cooling systems, construction metarials, building geometries, weather data and occupant schedules. The outputs of the software are heating/cooling loads and energy consumption of the building. The main advantage of using DesignBuilder is to analyse energy consumption of case building by adding renewable energy technologies such as solar panel, wind turbines etc.

The case building is modelled according to the geometry of the building, energy relevant properties of the materials, monthly climate parameters of Ankara, office equipments such as computers and photocopiers and occupant behaviours (Figure 3). Before the simulation, the model is calibrated with temperature and electricity consumption data of the case building. 
Figure 3. Model construction for Hasanoglan Atatürk Science High School

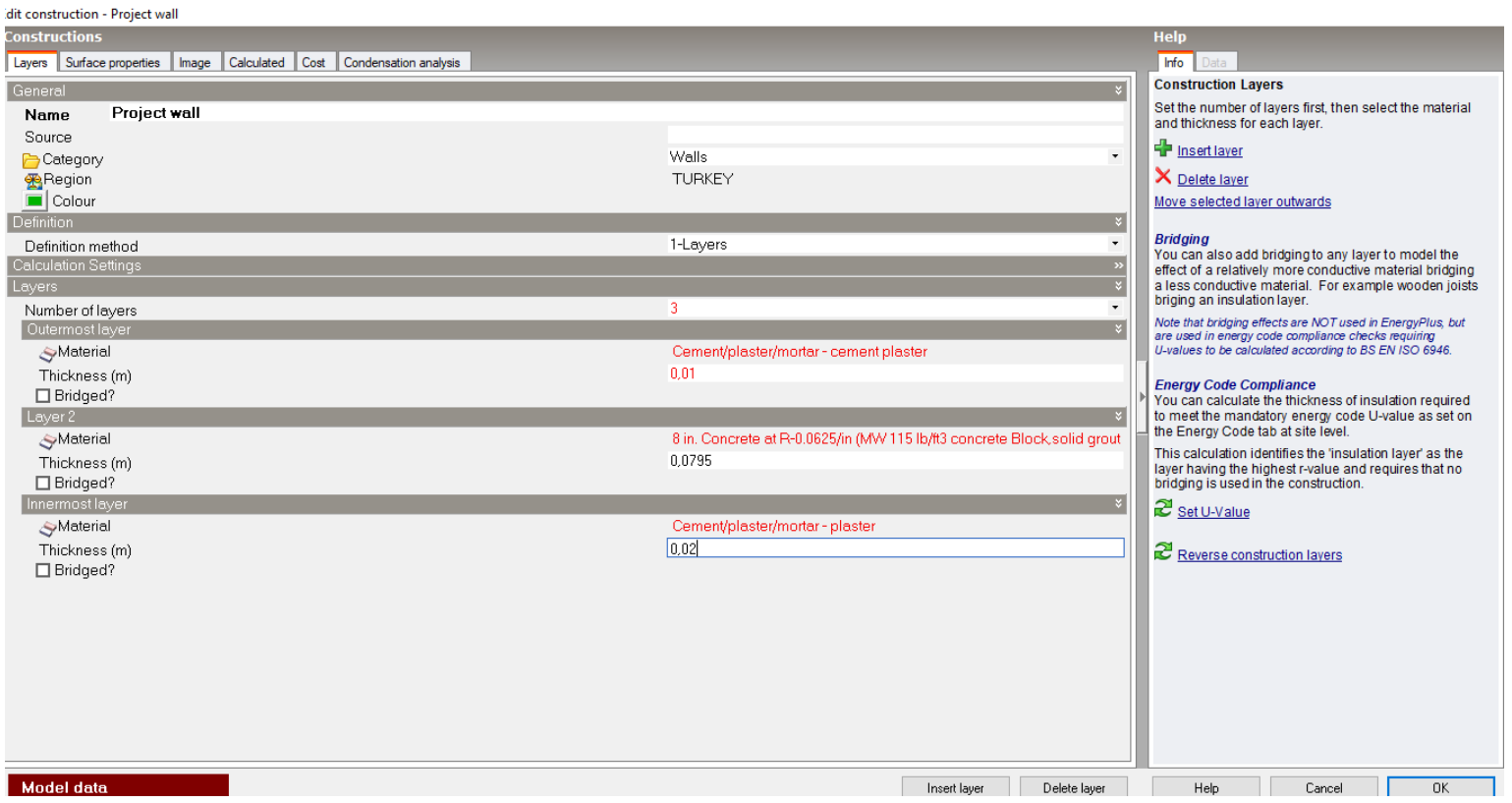

Eq. (1) and (2) were used to obtain heating and cooling energy requirements of case building according to the European Standards (EN 892, 1999).

$$
\begin{aligned}
& Q_{h}=Q_{h L}-\eta_{h g} Q_{g h} \\
& Q_{c}=Q_{c L}-\eta_{c g} Q_{g c}
\end{aligned}
$$

where $Q_{h}$ and $Q_{c}$ heating and cooling energy requirements, respectively. $Q_{h L}$ is total heat transfer for heating mode, $\eta_{h g}$ and $\eta_{c g}$ are dimensionless gain utilisation factors while $Q_{g h}$ and $Q_{g c}$ depict total heat sources for heating and cooling modes.

The energy retrofit scenarios are implemented in order to reduce energy consumption of Hasanoglan Atatürk Science High School after the current energy performance is analysed via DesignBuilder simulation tool. Six different energy retrofit scenarios are taken as given below.

A: Decreasing or increasing the set-temperature by $1{ }^{\circ} \mathrm{C}$ according to the season (from $23{ }^{\circ} \mathrm{C}$ to $22{ }^{\circ} \mathrm{C}$ for winter, from $23{ }^{\circ} \mathrm{C}$ to $24{ }^{\circ} \mathrm{C}$ for summer).

$\underline{B}$ : Decreasing the air tightness in order to reduce energy consumption (from $0.71 / \mathrm{h}$ to $0.51 / \mathrm{h})$.

$\underline{C}$ : Changing windows with quadruble low-e windows.

$\underline{D}$ : Ten PV panels (1.6 X $1 \mathrm{~m}$, with standard 60 cells) with a total area of $16 \mathrm{~m}^{2}$ were applied to produce electricity for the building.

$\underline{E}$ : Solar collector with a total area of $2.06 \mathrm{~m}^{2}$ were implemented to decrease energy consumption and supply domestic hot water.

$\underline{F}$ : Adding one three-bladed wind turbine to generate electricity (with $31 \mathrm{~m}$ height and $55 \mathrm{~kW}$ rated power output) (Figure 4) 
Figure 4. Adding wind turbine in BES tool for Hasanoglan Atatürk Science High School

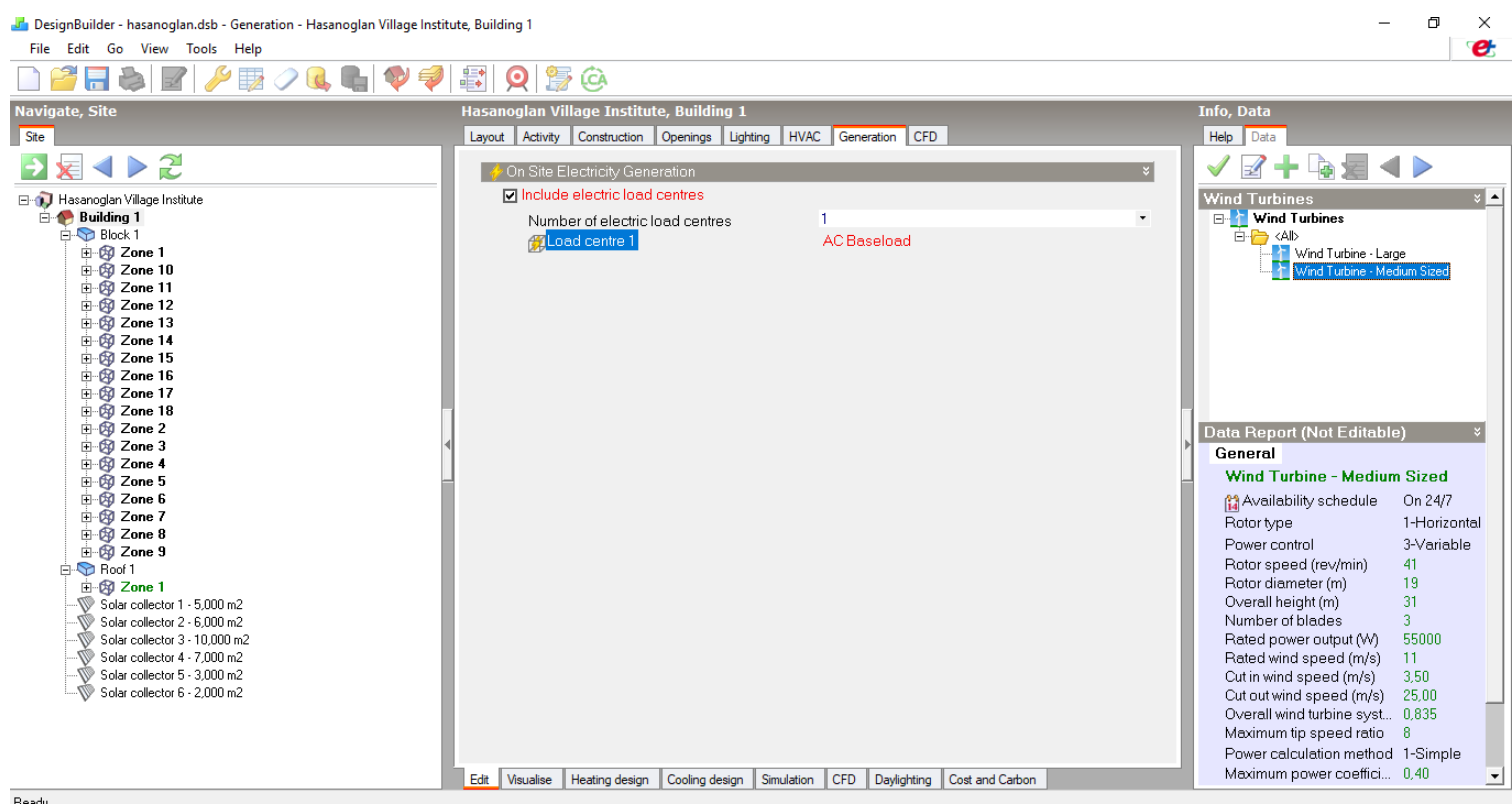

Table 1 depicts the description of six retrofitting scenarios in detail. Based on the reduction of energy consumption, pay-back periods are calculated according the formula in Eq.3 (Turhan et al., 2016).

Pay-back Period: Investment Cost/ Annual Cash Savings

Table 1. Retrofitting Scenarios

\begin{tabular}{|c|c|c|c|}
\hline Scenarios & Retrofits & Existing & Improved \\
\hline Case 1 & $A$ & $23{ }^{\circ} C$ & $\begin{array}{c}22{ }^{\circ} \text { C for winter, } 24 \\
{ }^{\circ} \text { C for summer }\end{array}$ \\
\hline Case 2 & $A+B$ & $0.71 / \mathrm{h}$ & $0.5 \mathrm{l} / \mathrm{h}$ \\
\hline Case 3 & $A+B+C$ & $1.98\left(\mathrm{~W} / \mathrm{m}^{2} \mathrm{~K}\right)$ & $0.77\left(\mathrm{~W} / \mathrm{m}^{2} \mathrm{~K}\right)$ \\
\hline Case 4 & $A+B+C+D$ & - & $2 \mathrm{kWp}$ \\
\hline Case 5 & $A+B+C+D+E$ & - & $2 \mathrm{kWh}$ \\
\hline Case 6 & $A+B+C+D+E+F$ & - & $55 \mathrm{~kW}$ \\
\hline
\end{tabular}

\section{RESULTS AND DISCUSSION}

The BES model is calibrated according to the ASHRAE Guideline 14 (ASHRAE, 2002). Six different energy retrefitting scenarios are implemented after constructing and calibrating model accurately. Figure 5 shows the final model of the Hasanoglan Atatürk Science High School after implementing six energy retrofitting scenarios including renewable energy technologies. 
Figure 5. Decreasing energy consumption of Hasanoglan Atatürk Science High School towards a nearly-zero energy building

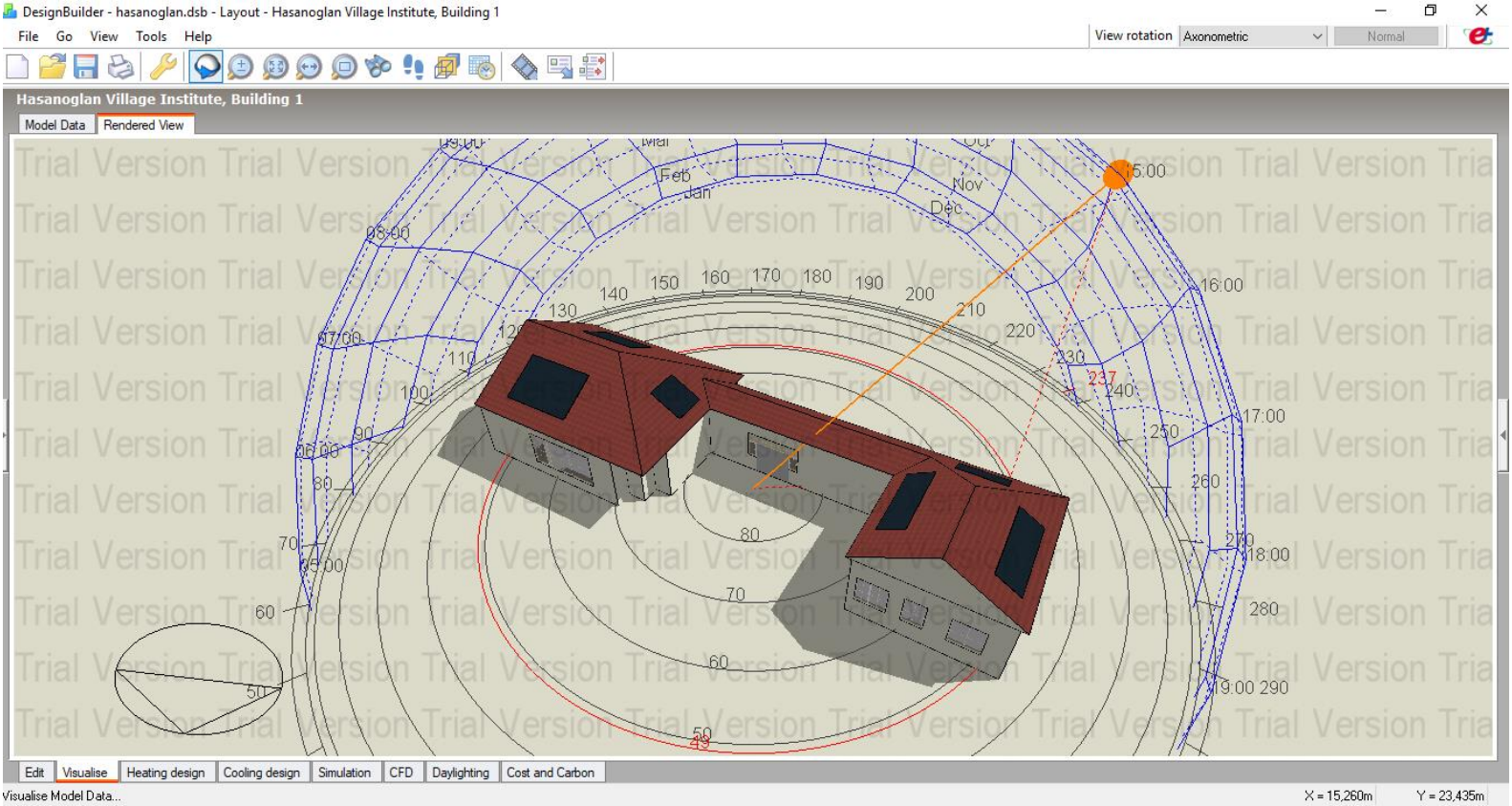

The reduction in energy consumption for the case building is shown in Figure 6. Changing the set-temperature of heating and cooling system saves $2.6 \%$ of energy without any pay-back period. Since the window number in the building is low, changing the window type to high performance low-e windows seems not logical (pay-back period is 7.8 years). Results show that retrofit Case 4 reduces the total annual energy consumption by $12 \%$. With adding solar collector to the system, $15 \%$ of energy can be saved with a pay-back period of 8.4 years.

Figure 6. The total energy consumption of retrofits

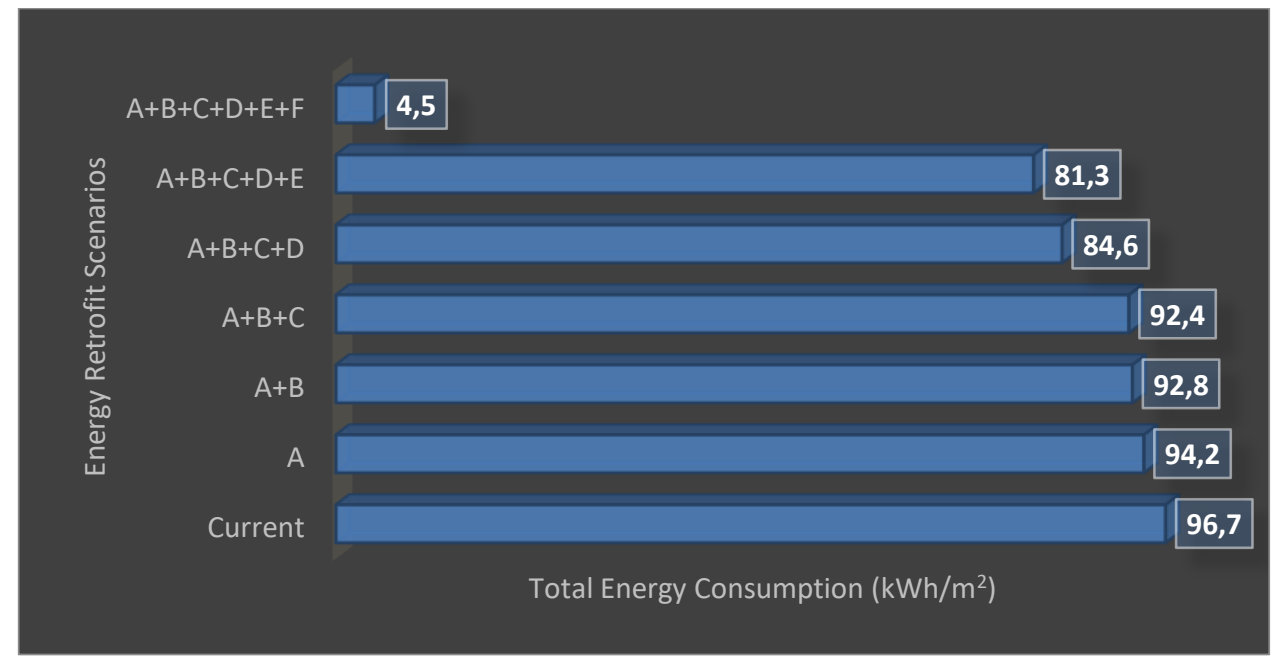

However, the most important retrofit is implementing wind power system to the Hasanoglan Atatürk Science High School building. The initial costs of constructing a $31 \mathrm{~m}$ wind turbine is around 50000 pounds. This number can be seemed as high with a pay-back period of 14 years. However, implementing wind power system to the Hasanoglan Atatürk Science High School saves $95.3 \%$ of energy. Furthermore, by increasing the number or power of wind turbines, the Hasanoglan Atatürk Science High School can sell electricity to the city 
electricity grids which can make the building "positive-energy building". Table 2 summarizes the energy retrofit scenarios and energy savings with pay-back periods.

Table 2. Energy consumption of the Hasanoglan Atatürk Science High School with respect to energy retrofits

\begin{tabular}{|c|c|c|c|c|c|}
\hline & $\begin{array}{c}\text { Total energy } \\
\text { consumption } \\
(\mathrm{kWh} / \text { year })\end{array}$ & $\begin{array}{c}\text { Total energy } \\
\text { consumption per area } \\
\left(\mathrm{kWh} / \mathrm{m}^{2} \text { year }\right)\end{array}$ & $\begin{array}{c}\text { Energy } \\
\text { Saving (\%) }\end{array}$ & $\begin{array}{c}\text { Cost } \\
(\mathrm{TL})\end{array}$ & $\begin{array}{c}\text { Pay-back } \\
\text { period } \\
\text { (Year) }\end{array}$ \\
\hline $\begin{array}{c}\text { Case } \\
\text { educational } \\
\text { building }\end{array}$ & 14586 & 96.69 & - & - & - \\
\hline Case 1 & 14203.7 & 94.15 & 2.62 & - & - \\
\hline Case 2 & 14001.04 & 92.81 & 4.01 & 150 & 0.48 \\
\hline Case 3 & 13949 & 92.40 & 4.36 & 4750 & 7,81 \\
\hline Case 4 & 12763.14 & 84.60 & 12.49 & 20990 & 8.41 \\
\hline Case 5 & 12261.73 & 81.28 & 15.93 & 26240 & 8.49 \\
\hline \multicolumn{7}{|c|}{ Case 6 } & 678.24 & 4.49 & 95,35 & 405095 & 14,11 \\
\hline \multicolumn{7}{|l|}{ Note: Labour charges are added to the prices, $1 \$=5.8 T L, 1 £=7.57 T L, 1 €=6.55 T L$} \\
\hline
\end{tabular}

\section{CONCLUSIONS}

An administrive building in Hasanoglan Atatürk Science High School Campus was selected as a case study in order to apply zero-energy building concept. The energy performance of the case building was simulated via of Design Builder building energy performanse simulation program. The tool was calibrated with real data according to the standards. The improvements in decreasing the energy consumption applying various retrofitting scenarios were shown. The results show that using renewable energy sources such as solar and wind power, $95 \%$ of energy consumption can be saved. Another outcome of the study is that the energy consumption of educational buildings such as Hasanoglan Atatürk Science High School should be lower with a development of technology and using renewable energy sources. Note finally that this study is an elementary work which does not include whole buildings in campus. By applying energy retrofits to the whole buildings, more energy savings would be obtained. Furthermore, energy efficiency of the Hasanoglan Atatürk Science High School can be improved by using more efficient appliances, lighting system and raising awareness on energy efficiency of the administrator and students.

\section{ACKNOWLEDGEMENT}

The authors would like to thank administration of Hasanoğlan Atatürk Science High School for their valuable help in order to obtain dimensions and photographs. 


\section{REFERENCES}

ASCIONE, F., BIANCO, N., DE MASI, R.F., DE'ROSSI, F., VANOLI, GP., 2015, Energy retrofit of an educational building in the ancient center of Benevento. Feasibility study of energy savings and respect of the historical value, Energy and Buildings, 95, 172183.

ASHRAE, AG., 2002, ASHRAE Guideline 14: Measurement of Energy and Demand Savings, American Society of Heating, Refrigerating and Air-Conditioning Engineers.

BASARIR, B., SAHIN DIRI, B., DIRI, C., 2012, Energy efficient retrofit methods at the building envelopes of the school buildings, www.academia.edu/Ellipsis/Energy_efficient_retrofit_methods_at the building_envel opes (Access Date: 30.07.2019).

DESIGNBUILDER, v6.1.0.006, http://www.designbuilder.co.uk/ (Access Date: 10.05.2019)

EN 832, 1999, Thermal performance of buildings, calculation of energy use for heating, residential buildings.

ESHRAGHI, J., NARJABADFAM, N., MIRKHANI, N., KHOROSHAHI, S., ASJAEE, M., 2014, A comprehensive feasibility study of applying solar energy to design zero energy building for a typical home in Tehran, Energy and Buildings, 72, 329-339.

KARAOMERLIOGLU, A., 1998, The Village Institutes Experience in Turkey, British Journal of Middle Eastern Studies, 25(1), 59-70.

KORUR, A. F., 2002, Democratic education, the village institutes system in Turkey and its art education component, Ph.D. Thesis, Ohio State University, Colombus, OH.

SAIT, HH., 2013, Auditing and analysis of energy consumption of an educational building in hot and humid area, Energy Conversion and Management, 66,143-152.

TONGUC VAKFI, 2019, http://www.tongucvakfi.org.tr/village-institutes.html

TURKISH STATE METEOROLOGICAL SERVICE, https://www.mgm.gov.tr/veridegerlendirme/il-ve-ilceler-istatistik.aspx (Date Access: 10.05.2019)

TURHAN, C., COŞKUN, T., DURMUŞ ARSAN, Z., GÖKÇEN AKKURT, G., 2016, Energy Efficient Retrofits in Residential Buildings in Turkey: A Case Study for a Flat in Izmir, $8^{\text {th }}$ International Ege Energy Syposium, May 11-13, 2016, Afyonkarahisar.

VEXLIARD, A. and AYTAÇ, K., 1964, The Village Institutes in Turkey, Comparative Education Review, 8 (1), 41-47.

WORLD MAP OF KOPPEN-GEIGER CLIMATE CLASSIFICATION, 2006.

ZEILER, W., BOXEM, G., 2013, Net-zero energy building schools, Renewable Energy, 49, 282-286. 